\title{
A NEW SPECIES OF DEPARIA FROM NEW GUINEA
}

Received October 17, 2021; accepted December 06, 2021

\section{WITA WARDANI}

Herbarium Bogoriense, Research Center for Biology, National Research and Innovation Agency. Jln. Raya JakartaBogor, Km. 46, Cibinong, West Java 16911.Email: wt.wardani@gmail.com

\author{
JAENUDIN \\ Herbarium Bogoriense, Research Center for Biology, National Research and Innovation Agency. Jln. Raya Jakarta- \\ Bogor, Km. 46, Cibinong, West Java 16911.Email: jayrakanoval@gmail.com
}

\section{ISMAIL APANDI}

Herbarium Bogoriense, Research Center for Biology, National Research and Innovation Agency. Jln. Raya JakartaBogor, Km.46, Cibinong,West Java16911.Email: ismailapandi77@gmail.com

\author{
ANNE KUSUMAWATY \\ Herbarium Bogoriense, Research Center for Biology, National Research and Innovation Agency. Jln. Raya Jakarta- \\ Bogor, Km. 46, Cibinong, West Java 16911.Email: annekusuma01@yahoo.co.id
}

\section{WAHYUDI SANTOSO}

Herbarium Bogoriense, Research Center for Biology, National Research and Innovation Agency. Jln. Raya JakartaBogor, Km.46, Cibinong, West Java 16911.Email: wahygbr@gmail.com

\begin{abstract}
WARDANI, W., JAENUDIN, APANDI, I., KUSUMAWATY, A. \& SANTOSO, W. 2021. A new species of Deparia from New Guinea. Reinwardtia 20(2): 57-61. - Deparia stellata is a new species of highland in Eastern New Guinea, described from a specimen found among unidentified piles of New Guinean Expedition in 1975. Its distinctive stellate-hairs on all axis and occasionally on rachis-scale margin are the main character that differentiate the species to other Deparia.
\end{abstract}

Key words: Deparia, highland, New Guinea, stellate-hairs.

\begin{abstract}
ABSTRAK
WARDANI, W., JAENUDIN, APANDI, I., KUSUMAWATY, A. \& SANTOSO, W. 2021. Jenis baru Deparia dari Papua Nugini. Reinwardtia 20(2): 57-61. - Deparia stellata adalah jenis baru dari dataran tinggi Papua Nugini bagian timur, dideskripsikan dari satu spesimen yang tidak teridentifikasi dalam tumpukan hasil ekspedisi di Papua Nugini pada tahun 1975. Karakter utama yang membedakannya dari jenis lain pada marga Deparia adalah tutupan rambut-rambut bintang di semua sumbu (rakis, kosta kostul dan vena) dan terkadang pada tepian sisik di bagian rakis.
\end{abstract}

Kata kunci: Dataran tinggi, Deparia, Papua Nugini, rambut bintang.

\section{INTRODUCTION}

Among specimens of Athyriaceae from New Guinea stored in BM, we found an interesting specimen that could not be convincingly identified. The pinnate oblong-lanceolate leaf with pinnae deeply incised, gradually reduced to pinnae with serrated margin toward apex, groovy and hairylook axis, and linear indusium that mostly not reaching margin are some of the main features of a common species, Deparia petersenii, that immediately observed in our specimen. It was collected on the Star Mountains Expedition in 1975, a collaborative trip between Papua New Guinea National Herbarium (LAE) and Rijksherbarium Leiden (L).
After a closer examination, we found the lamina axes of this specimen are densely covered with distinctive indumentum of darkly-pigmented stellate hairs, rather than multicellular septate hairs as commonly found in other Deparia species. Moreover, their scales are different from some hairs on margin that are not present in most of Deparia. This character is unusual for the genus and suggest that this specimen represented an undescribed species.

Deparia is a wide spread genus in the family Athyriaceae, distributed in tropical Africa, Madagascar, Reunion, South India, Ceylon, Himalayas, East and South East Asia, Oceania, East Australia and East North America (Kato, 1984). This terres- 
trial fern includes several other previously recognized genera i.e. Dryoathyrium Ching, Lunathyrium Koidz., Parathyrium Holttum, Athyriopsis Ching (Kato, 1984; Sano et al., 2000; Wang et al., 2013), Triblemma (J.Sm.) Ching and Dictyodrama Ching (Sano et al., 2000; Wang et al., 2003). Deparia differs from other genera in the Athyriaceae in its discontinued groove at the junction of costae and rachis (Kato, 1984) combined with the presence of multicellular (septate) hairs (Sundue \& Rothfels, 2014; Rothfels et al., 2012).

\section{MATERIALS AND METHODS}

Herbarium specimen of Deparia stored in BO and a loan from $\mathrm{BM}$ were gathered for observation and sorted based on morphology. Detail examina- tion were carried using Olympus stereo microscope SZ61 equipped with long arm, calibrated eyepiece and camera (Fig. 1).

\section{RESULTS AND DISCUSSION}

Kuo et al. (2018) recognized five sections with three subsections in its infrageneric classification, i.e. Dryoathyrium, Lunathyrium, Erectus, Dictyodrama, Deparia with sub sections Deparia, Caespites and Athyriopsis. This classification is in line with grouping presented in Kato (1984) for Pacific species. Following the key to section provided in Kato (1984) this presented new species is in between the Sect. Deparia and Sect. Athyriopsis since it has entire indusia but slender rhizome.

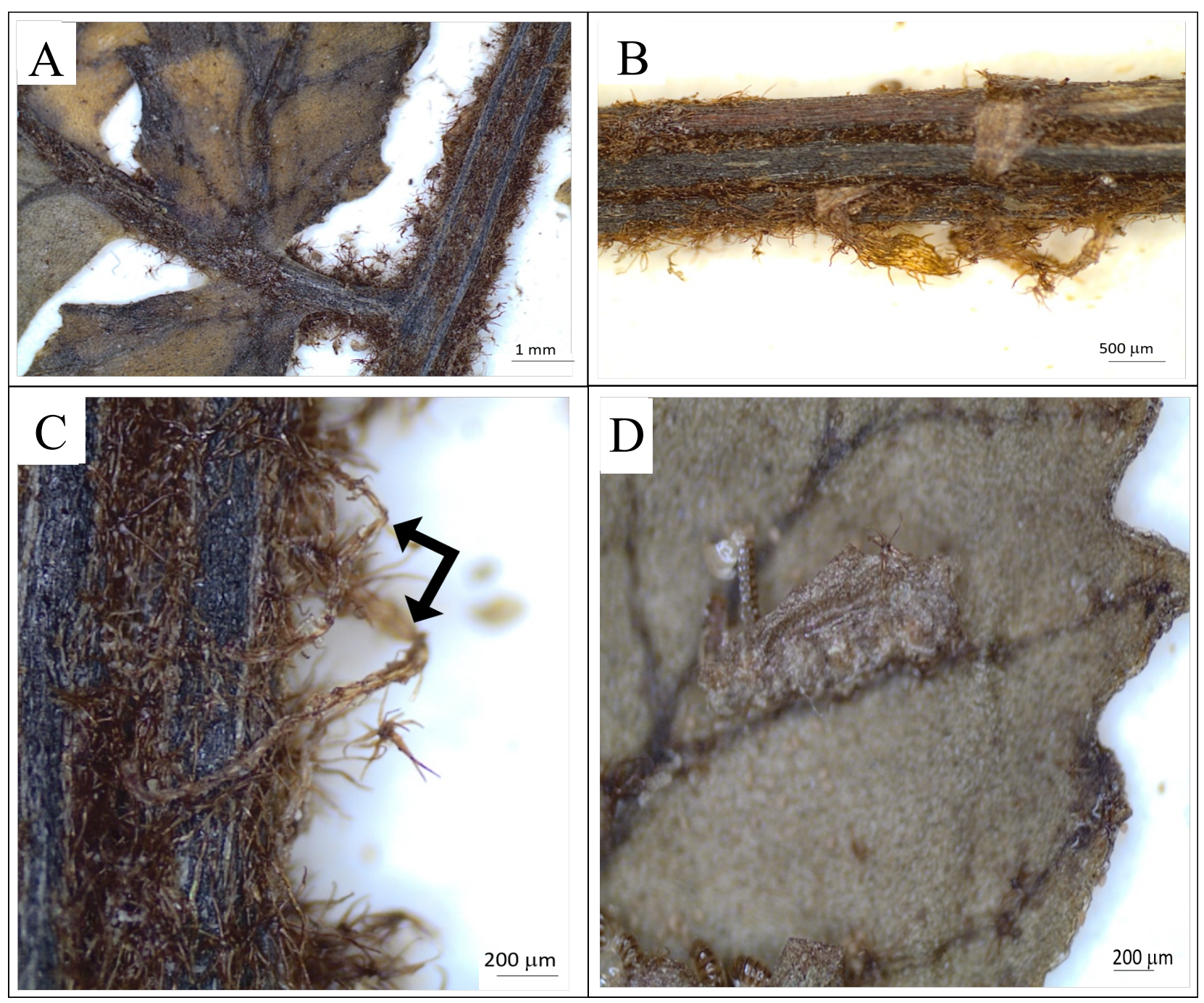

Fig. 1. A. Rachis densely covered with dark-stellate hair. Also showing the discontinued groove at the junction of costae and rachis. B. Stipe scale with irregular stiff hair on its margin. C. Two pieces of septate hair on rachis, appear among stellate hair. D. Indusium with stiff hairs radiate from one point on the margin. From W. R. Barker 67491. Photos by W. Wardani. 


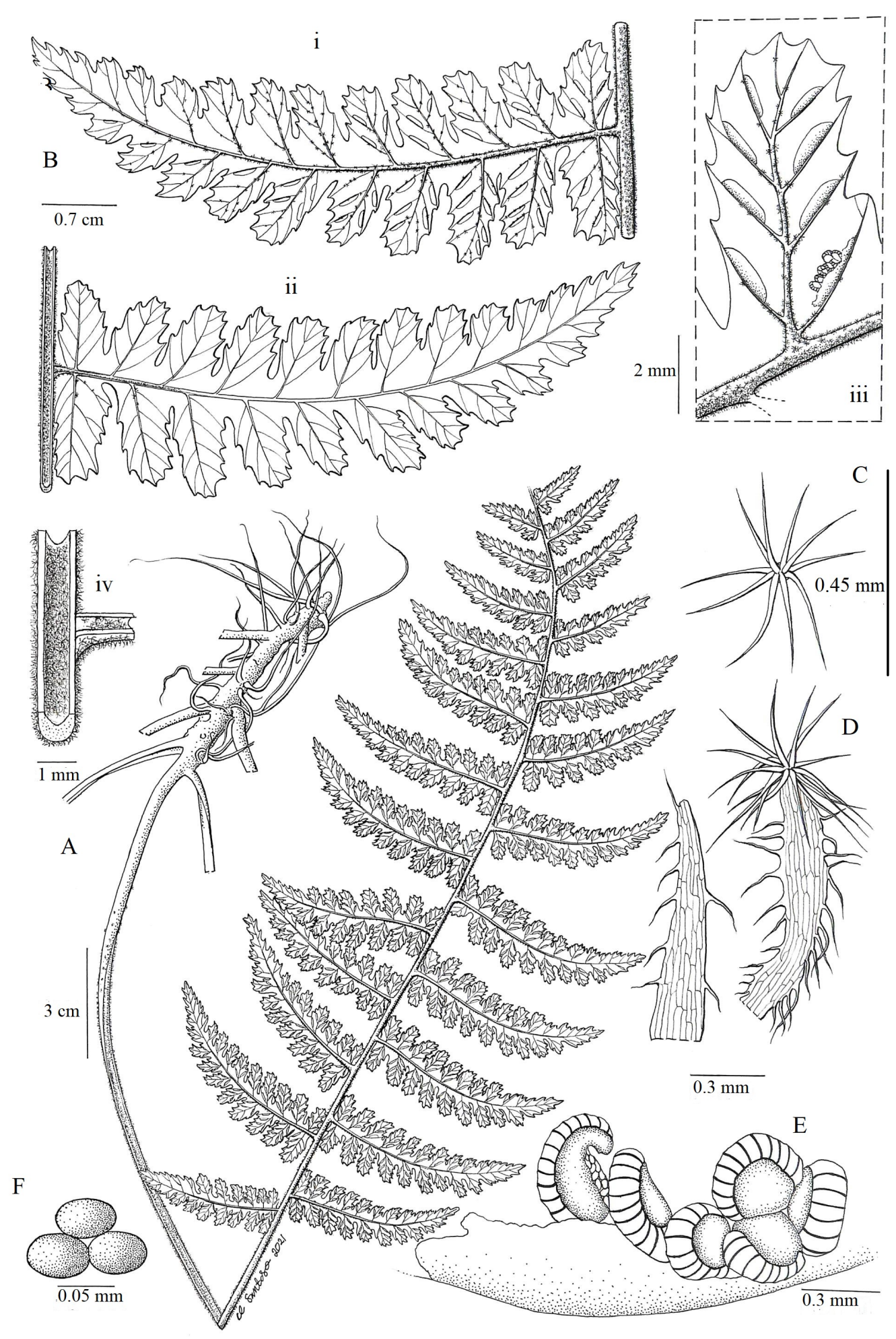

Fig. 2. Deparia stellata Wardani spec. nov. A. Habit. B. Portion of pinnae of abaxial (i) and adaxial (ii) side, detail of indusium underneath (iii) and groove at the junction of rachis and costae (iv). C. Stellate hair. D. Scale with stiff hairs on margin and stellate hair at apex. E. Detail of sporangium below indusium. F. Bilateral spore. From W. R. Barker 67491. Drawn by W. Santoso. 


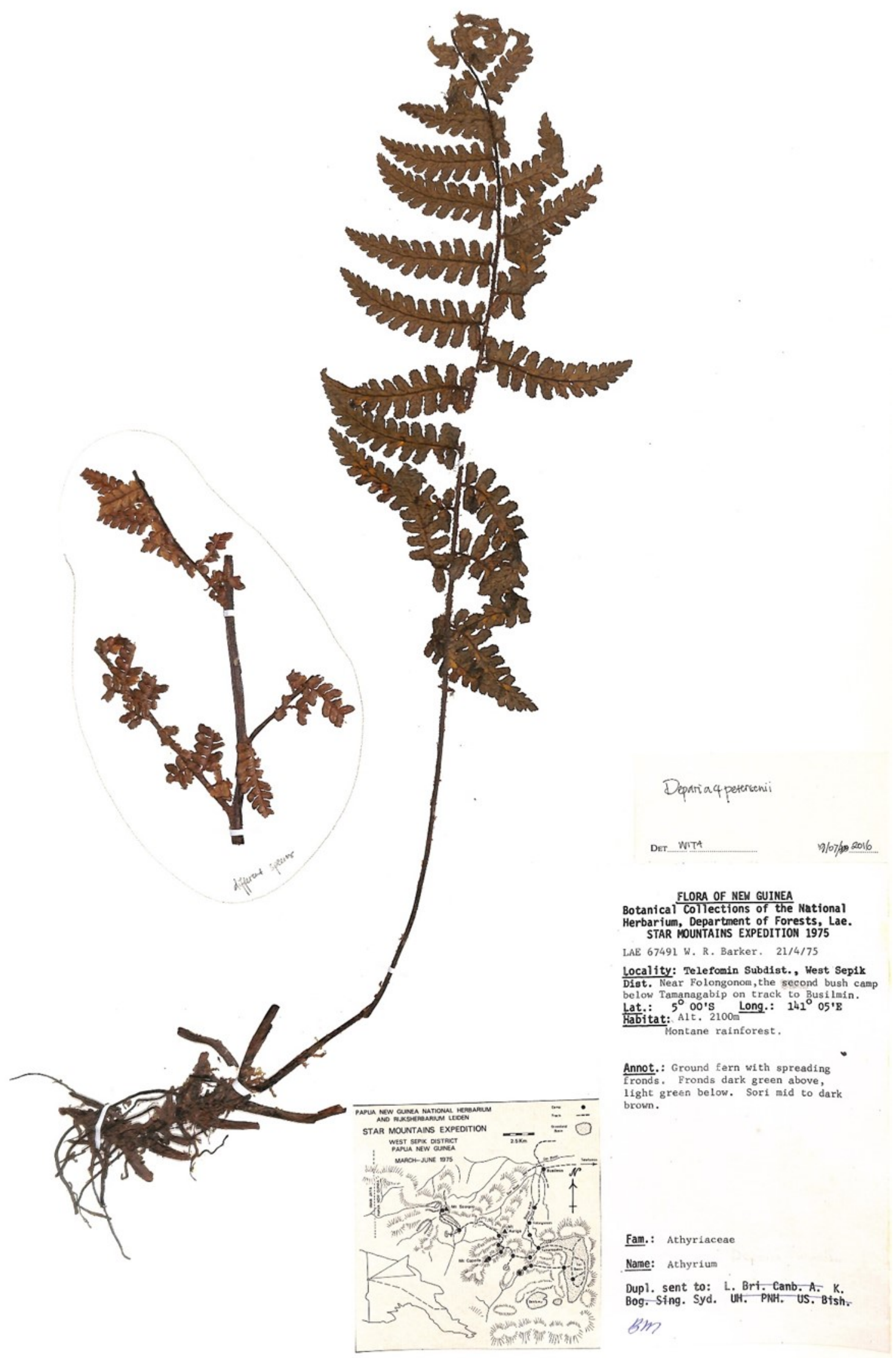

Fig. 3. Scanned holotype specimen of Deparia stellata Wardani spec. nov. From W. R. Barker 67491. Scanned by Jaenudin. 
Deparia stellata Wardani spec. nov. Figs. 1-3. - TYPE: PAPUA NEW GUINEA. District West Sepik, Subdist. Telefomin, $5^{\circ} 00^{\prime} \mathrm{S} 141^{\circ} 05^{\prime} \mathrm{E}, 2,100$ $\mathrm{m}$ asl near the border with Indonesia, 21 April 1975, W. R. Barker 67491 (Holotype BM! Isotype L).

Pinnate-pinnatifid leaf, groovy axis, discontinue at the junctions. Rachis, costae and costules covered with darkly-pigmented stellate hair, while the multicellular septate hair as commonly occur in Deparia is sparsely present. Scale margin ornamented with hairs.

Rhizome creeping, slightly ascending, $4.6 \mathrm{~mm}$ thick. Stipe blackish, $18.5 \mathrm{~cm}$ long, scales caducous, brown, about $0.3 \mathrm{~mm}$ wide and $2 \mathrm{~mm}$ long, irregularly with stiff hairs on margin, unlike the entire margin in most of Deparia species. Lamina lanceolate, gradually acuminate, slightly reduced downward, herbaceous, $23-33.5 \mathrm{~cm}$ long, $11 \mathrm{~cm}$ wide, pinnate-pinnatifid, one or two basal pinnae pairs with separated acroscopic basal segment. Pinnae $1.7-2.4 \mathrm{~cm}$ apart, deeply pinnatifid and serrated lobes, up to $6 \mathrm{~cm}$ long and $1.62 \mathrm{~cm}$ wide with $1.45 \mathrm{~mm}$ stalks, acuminate, acroscopic basal segment $8 \mathrm{~mm}$ long and $4.3 \mathrm{~mm}$ wide, $3 \mathrm{~mm}$ apart. All axes of both sides bearing dark stellate hairs 0.45 $0.9 \mathrm{~mm}$ in diameter, especially dense on the rachis and pinnae stalks, replace the septate hairs that commonly occur in other Deparia species. The long septate hairs only sparsely present on rachis. Smaller scales as on stipe also present on rachis, with hairs on margin. Sori linear on veins, indusia thin, $1.85-3 \mathrm{~mm}$ long, entire, sometimes ornamented with few $\pm 0.12 \mathrm{~mm}$ long stiff hair on margin, radiating from a point impressing an abraded stellate hair.

Distribution. Known only from the type location.

Habitat. In a pristine forest at high altitude of New Guinea, 2,100 $\mathrm{m}$ asl.

Etymology. The epithet refers to the distinctive stellate hair covering rachis and basal pinnae-stalk, and also alludes to the type locality, the Star Mountains.

Note. The duplicate specimen in L were stored under Diplazium stellatopilosum (Brause) Holttum
(L.3525651) which is a very different species that has similar unusual hair covering (Holttum \& Roy, 1965).

\section{ACKNOWLEDGEMENTS}

We thank Alison Paul (BM) for her assistance during the herbarium visit and for the loan arrangement. We also thank BM for lending the pile of specimen for such a prolonged duration. We thank reviewers for all suggestions and comments that improve clarity of our manuscript.

\section{REFERENCES}

HOLTTUM, R. E. \& ROY, S. K. 1965. Cytological observation on ferns from New Guinea with description of new species. Blumea 13: 129-139.

KATO, M. 1984. A taxonomic study of the Athyrioid fern genus Deparia with main reference to the Pacific species. Journal Faculty of Science University of Tokyo Section III 13: 371 $-430$.

KUO, L. Y., EBIHARA, A., HSU, T. C., ROUHAN, G., HUANG, Y. M., WANG, C. N., CHIOU, W. L. \& KATO, M. 2018. Infrageneric revision of the fern genus Deparia (Athyriaceae, Aspleniineae, Polypodiales). Systematic Botany 43(3): 645-655.

ROTHFELS, C. J., SUNDUE, M. A., KUO, L. Y., LARSSON, A., KATO, M., SCHUETTPELZ, E. \& PRYER, K. M. 2012. A revised family level classification for eupolypod II ferns (Polypodiidae: Polypodiales). Taxon 61(3): 515-533.

SANO, R., TAKAMIYA, M., KURITA, S., ITO, M. \& HASEBE, M. 2000. Diplazium subsinuatum and D. tomitaroanum should be moved to Deparia according to molecular, morphological and cytological characters. Journal of Plant Research 113(2): 157-163.

SUNDUE, M. A. \& ROTHFELS, C. J. 2014. Stasis and convergence characterize morphological evolution in eupolypod II ferns. Annals of Botany 113(1): 35-54.

WANG, M. L., CHEN, Z. D., ZHANG, X. C., LU, S. G. \& ZHAO, G. F. 2003. Phylogeny of Athyriaceae: evidence from chloroplast trnL-F region sequences. Acta Phytotaxonomica Sinica 41: 416-426. 
